\title{
SOCIAL HOUSING DI INDONESIA: KAJIAN PROSPEK MENGGUNAKAN ANALISIS MODEL SYSTEM DYNAMIC
}

\author{
Andreas Agung Widhijanto ${ }^{1)}$, Iwan Priyoga ${ }^{2)}$ \\ Universitas Pandanaran \\ Jalan Banjarsari Barat No.1 Pedalangan Banyumanik, Semarang, Indonesia \\ Email $^{1)}$ : andreas.widhiyanto@gmail.com \\ Email $^{2}$ : iwan.priyoga@unpand.ac.id
}

\begin{abstract}
ABSTRAK
Social housing adalah rumah sewa yang diselenggarakan oleh pemerintah yang diperuntukan bagi masyarakat tidak mampu secara finansial atau kondisi tertentu. Social housing memiliki 3 prinsip penyelenggaraan yaitu: dilakukan oleh pemerintah, dalam bentuk rumah sewa dan diperuntukkan bagi kelompok yang tidak/kurang mampu, termasuk hal finansial. Pemahaman penyelenggaraan di Indonesia dengan merujuk Undang-undang No. 1 tahun 2011 tentang Perumahan dan Kawasan Permukiman lebih bersifat 'charity' atau akan di-support oleh pemerintah melalui pembiayaan public pada pasal 21 untuk rumah "kebutuhan khusus", antara lain: kebutuhan untuk perumahan transmigrasi, pemukiman kembali korban bencana, dan rumah sosial untuk menampung orang lansia, masyarakat miskin, yatim piatu, dan anak terlantar, serta termasuk untuk pembangunan rumah yang lokasinya terpencar dan rumah di wilayah perbatasan negara Kondisi-kondisi di atas menjadi isu generik karena menimbulkan pertanyaan tentang pembangunan perumahan. Riset ini menggunakan analisis analisis secara kritis, critical analysis/review. Proses analisis menggunakan metoda menyusun konseptual melalui pendekatan secara sistem. Metoda ini adalah metoda 'Berpikir Sistem' dengan memiliki keterkaitan sifat causa dan affect antara variabel satu dengan lainnya dalam kerangka berpikir sebagai sistem atau system thinking. Akhirnya, kesimpulan riset Prospek Social Housing di Indonesia merupakan prospek membangun karakter social housing dan mengembangkan kriteria dan parameter keberadaan social housing. Prospek ini memberikan pemahaman kembali bahwa social housing merupakan instrumen pembangunan (kesejahteraan) sosial melalui penyediaan perumahan sesuai dengan standar baku. Penyediaan dilakukan melalui kemitraan sebagai pengembangan sistem (delivery). Sistem yang dikembangkan untuk mengendalikan akses dan alokasi pasar perumahan, sehingga social housing diselenggarakan berdasarkan stratifikasi karakter kelompok sasaran di perkotaan/urban dalam mengembangkan produktivitas melalui akomodasi perumahan.
\end{abstract}

Kata Kunci: right to housing, social welfare housing, social housing, system thinking, dan prospek. 


\section{PENDAHULUAN}

Pembahasan Social Housing di Indonesia diawali oleh pertanyaan mengapa social housing dipandang penting dan perlu. Kebijakan dan sistem pembangunan perumahan cenderung menempatkan rumah adalah hasil 'akhir' dari proses pembangunan atau housing is an 'end'. Kondisi ini menempatkan posisi pembangunan perumahan dipandang sebagai pembangunan fisik dibanding pembangunan perumahan untuk kesejahteraan sosial. Hal tersebut berkembang menjadi isu-isu generik yang mempertanyakan antara sistem penyediaan perumahan dibangun sebagai pemenuhan hak perumahan dan peningkatan kesejahteraan sosial masyarakat. Pertanyaan ini mendorong pemikiran: bagaimana membangun suatu sistem yang mengintegrasikan antara kedua sektor pembangunan tersebut dan meletakkan social housing sebagai katalisator penyelenggaraan kedua tujuan tersebut.

\section{Isu generik: Hak Perumahan versus Kesejahteraan Sosial}

Pemikiran mendasar dari kondisi pada gambaran umum adalah adanya pertentangan penyediaan perumahan bagi masyarakat dalam kerangka pemenuhan hak-hak atas perumahan (right to housing) dan upaya-upaya peningkatan kesejahteraan sosial (social welfare). Keberadaan social housing menjadi isu generik yang mendorong 2 (dua) pemikiran. Pertama, social housing merupakan sistem penyediaan perumahan yang mengintegrasikan antara right to housing dan social welfare. Implementasinya bukan merupakan pembangunan secara domain tertentu. Kedua, penyelenggaraannya merupakan katalisator untuk mencapai keduanya dalam bentuk suatu instrumen penyelenggaraan pembangunan.

\section{Pemahaman umum social housing}

Sementara ini, secara umum social housing dipahami sebagai suatu bentuk penyediaan perumahan sewa ${ }^{1}$ yang

\footnotetext{
${ }^{1}$ Saat ini, beberapa pemahaman umum masih mengartikan social housing merupakan rumah sewa,
}

diselenggarakan oleh pemerintah dan diperuntukkan bagi masyarakat tidak mampu, baik dalam hal finansial yaitu kelompok berpendapatan menengah ke bawah atau pada kondisi tertentu karena keterbatasan (fisik, usia ataupun kondisi sosial tertentu).

Sering dipertentangkan antara social housing dengan affordable housing. Namun, perbedaan prinsip social housing ${ }^{2}$ dan affordable housing ${ }^{3}$ adalah social housing lebih disediakan untuk perumahan sewa sedangkan affordable housing mengikuti kondisi pasar/market. Disamping itu social housing lebih mengarah kepada penyediaan kebutuhan rumah di bawah harga pasar sedangkan affordable housing menekankan kepada penyediaan rumah dengan harga lebih murah yang secara umum terjangkau. Keterjangkauan inilah yang menjadi pertimbangan mendasar dalam penyediaan perumahan, yaitu memenuhi kebutuhan dasar/basic need hak untuk mendapatkan rumah atau right to housing.

Pemahaman social housing ini mengindikasikan adanya 3 (tiga) prinsip dalam implementasinya yaitu: (i) diselenggarakan oleh pemerintah $^{4}$, (ii) dalam bentuk rumah sewa dan

walaupun dalam perkembangannya banyak kebijakan yang telah bergeser dari sistem ini, seperti leasing, joint operation, share capital dan sebagainya. Hal ini akan dibahas lebih mendalam pada bab Kajian.

${ }^{2}$ Social housing is housing of an adequate standard which is provided to rent (or on a shared ownership basis) at below market cost for households in need by Local Authorities or Registered Social Landlords operating on a basis of accepted and regulated standards of good practice in relation to physical conditions, management, allocation, equal opportunities and accountability to tenants and other stakeholders".

${ }^{3}$ Affordable housing is housing of an adequate standard which is cheaper than that which is generally available in the local housing market. ${ }^{4}$ Secara prinsip, pemerintah menyelenggarakan social housing. Penyelenggaraan ini memiliki arti politis sedangkan implementasinya tidak sematamata demikian, seperti oleh sektor swasta, pemilik lahan, lembaga non profit, dan sebagainya. Pembahasan mendalam dilakukan pada bab 
(iii) diperuntukkan bagi kelompok yang tidak/kurang mampu (termasuk hal finansial). Ketiga prinsip ini menjadi batasan dalam penyelenggaraan social housing, walaupun dalam perkembangannya ternyata banyak aspek lain yang mempengaruhi, seperti perkembangan pengaruh dari masalah tanah/lahan, lingkungan, ekonomi, budaya, kesejahteraan (sosial), dan sebagainya.

\section{Pertanyaan Riset}

Pertanyaan pertama, apa karakter mendasar dari social housing yang menjadikan keberadaannya mampu mengintegrasikan atau menjadi katalisator antara housing right dan social welfare. Karakter ini akan memancing pertanyaan kedua, bagaimana social housing ini harus diselenggarakan.

Kedua pertanyaan riset tesebut mendorong timbulnya pertanyaan ketiga yang berkaitan dengan kondisi di Indonesia, yaitu bagaimana social housing di Indonesia akan diselenggarakan. Dan terakhir, pertanyaan keempat mencari masalah-masalah apa yang dihadapi penyelenggaraan social housing di Indonesia dalam memenuhi housing right dan social welfare.

\section{TUJUAN DAN MANFAAT}

Tujuan riset ini adalah menjawab sejauhmana prospek social housing jika diselenggarakan di Indonesia. Sedangkan tujuan khusus riset ini adalah:

1. Memahami karakter social housing yang dilakukan melalui:

2. Manganalisa bagaimana social housing diaplikasikan di Indonesia:

3. Melihat prospek aplikasi social housing

Sedangkan manfaat riset diarahkan bagi pengetahuan, agensi pembangun perumahan dan secara khusus bagi masyarakat.

1. Manfaat bagi pengetahuan adalah membuka fenomena baru keberadaan social housing.

berikutnya yang menjelaskan mengapa oleh pemerintah, bagaimana perkembangannya dewasa ini dan sebagainya.
Fenomena ini dapat membangun 'body of knowledge' sistem pengadaan perumahan di Indonesia khususnya bagi kelompok menengah ke bawah.

2. Manfaat bagi agensi pembangun perumahan adalah mendorong pemerintah untuk menyusun suatu kebijakan publik bagi penyelenggaraan social housing. Kebijakan ini akan diikuti perencanan bank tanah, integrasi dengan program perumahan lainya. Selanjutnya aplikasi kebijakan memacu desain-desain 'software' penyelenggaraan social housing seperti: desain pembiayaan pembangunan, desain kebijakan, penyusunan codes, standar/pedoman subsidi.

3. Manfaat bagi masyarakat adalah mendapatkan pengetahuan dan informasi bentuk, mekanisme dan pranata penyelenggaraan social housing dalam mendapatkan perumahan yang layak dalam rangka meningkatkan kesejahteraan (sosial).

\section{Kerangka pelaksanaan Metoda Riset}

Kerangka Riset ini dialurkan dalam 3 kerangka besar, yaitu kerangka kajian, analisis dan hasil dengan menunjukkan bahwa rangkuman ${ }^{5}$ yang dihasilkan melalui kajian juga digunakan kembali pada proses analisis. Hal ini bukan merupakan pengulangan, melainkan sebagai penegasan dan kembali sebelum ditajamkan pada proses analisis. Selanjutnya, analisis dilakukan melalui analisis secara analisis kritis, walaupun proses ini mendapat bantuan penggunaan metoda 'berpikir sistem'. di Indonesia.

\footnotetext{
${ }^{5}$ Resume ini yang akan menunjukkan karakteristik dari social housing berupa atribut-atribut penyelenggaraannya. Resume ini secara khusus memberikan gambaran tentang what social housing is? Dan what it does?

${ }^{6}$ Indikasi aplikasi akan menunjukkan bagaimana mengaplikasikan di Indonesia atau how to apply social housing? Aplikasi ini dapat juga memprediksikan criteria dan parameter tentang where atau when jika social housing akan diselenggarakan di Indonesia.
} 


\section{METODA RISET Kajian/Riset}

Kajian Social Housing ini merupakan Riset Kualitatif bersifat eksplorasi dan deskripsi. Eksplorasi dan Deskripsi. Kajian Riset meliputi kajian kepustakaan, empiris, dan opini para pakar. Kajian kepustakaan dilakukan melalui identifikasi karakter untuk mendapatkan teori dan pendekatan keberadaan social housing, sekaligus menjelaskan relasi antara fakta-fakta untuk mendapatkan fokus penelitian sesuai dengan kondisi di Indonesia. Hubungan ini membangun struktur pemahaman peneliti melalui identifikasi dan penjelasan relasi yang berkait dari fakta-fakta yang ada. (Verma and Beard ${ }^{7}$ dalam Judith Bell, 2006 ${ }^{8}$; Black and Champion, 1999 $)$. Pada Kajian empiris memaparkan penyelenggaraan social housing pada kasus beberapa negara dengan mengambil sejumlah unsur yang digeneralisasikan (sementara) sebelum dilakukan pengujian hipotetis. Pengujian hipotetis ini menyangkut ciri kasus atau karakter dari bagian-bagian yang lebih spesifik melalui nilai deskriptifnya. (Black and Champion, 1999) ${ }^{10}$. Sedangkan, kajian opini para pakar sering disebut dengan expert opinion dalam riset ini dikaitkan sebagai proses umpan balik positif (Gaine, 1996) ${ }^{11}$ untuk

\footnotetext{
${ }^{7}$ Kajian kepustakaan dalam teorinya merupakan kegiatan membangun konsep atau struktur teoritis yang mampu menjelaskan fakta dan keterkaitan antar mereka. Formulasi konsep ini mengindikasikan pemikiran atau jalinan yang hilang atau data tambahan yang diperlukan. Judith Bell, Doing your Research Project, Open University Press, McGraw Hill, 2005 diterjemahan: penerbit PT Indeks,Gramedia Group,2006.

${ }^{8}$ Judith Bell, Doing your Research Project, Open University Press, McGraw Hill, 2005 diterjemahan: penerbit PT Indeks, Gramedia Group,2006. ${ }^{9}$ Black, James A. dan Champion, Dean J., Metoda dan masalah Penelitian Sosial, Penerbit PT Refika Aditama, Bandung 1999 halaman 94

${ }^{10}$ Black, James A. dan Champion, Dean J., Metoda dan masalah Penelitian Sosial, Penerbit PT Refika Aditama, Bandung 1999 halaman 80.

${ }^{11}$ Gaines, Brian A., Positive Feedback Processes Underlying the Formulation of Experties,
}

mendapatkan wacana substansi. Secara teoritis, metoda ini merupakan model proses (berbentuk lingkaran/loops) dalam mengelola pendapat pakar secara induktif untuk memahami pengetahuan.

\section{Analisis}

Analisis riset ini secara keseluruhan merupakan analisis secara kritis, disebut dengan critical analysis/review. Dalam proses analisis ini, digunakan pula sebuah metoda untuk menyusun konseptual melalui pendekatan secara sistem. Metoda ini adalah metoda 'Berpikir Sistem'12 yang berangkat dari cara pandang bahwa permasalahan pada riset sosial adalah bersifat sangat kompleks. Sifat kompleks ditunjukkan pada keterkaitan sifat causa dan affect antara variabel satu dengan lainnya dalam kerangka berpikir sebagai sistem atau system thinking. Analisis ini lebih singkat dibanding system dynamic.

\section{ANALISIS RISET/KAJIAN}

Analisis adalah dengan mengeklorasikan hubungan sebab dan akibat dalam penyelenggaraan social housing melalui penentuan batasan sektor penyelenggaraan social housing, yaitu sektor perumahan dan kesejahteraan (sosial). Konsep ini memiliki keterkaitan pula dengan atribut-atribut ${ }^{13}$

Knowledge Science Institute, University of Calgary, Alberta, Canada, 1996.

${ }^{12}$ DeTombe, Dorien, Handling Complex Societal Problems, Chapter 17

http://www.geocities.com/doriendetombe/index.html Something is called a problem when there is a discrepancy between the actual or (near) future situation and the desired future situation and/or there is a lack of knowledge and/or a lack of knowhow, and/or a lack of relevant data; as for complex interdisciplinary societal problems, the problem is often undefined and the desired situation is not always clear (DeTombe, 1994: 58).

${ }^{13}$ Atribut-atribut ini merupakan keluaran hasil kajian, sedangkan mekanisme pasar menempatkan bagaimana social housing berperan sebagai penawaran produk pembangunan dan permintaan pemenuhan kebutuhan masyarakat. Pemerintah akan menempatkan dirinya sebagai penyeimbang 
penyelenggaraan social housing. Keduanya, menjadi masukan dalam menyusun model penyelenggaraan social housing berupa diagram alir penyelenggaraan. Model yang menunjukkan kondisi ideal penyelenggaraan social housing ini dianalisis secara kritis sesuai dengan kondisi di Indonesia. Eksplorasi deskripif susunan model penyelengaraan social housing terhadap sifat causa dan affect antara variabel yang terdiri dari:

1. Hubungan substansi pada keterkaitan konsep

2. Hubungan sebab dan akibat pada sektor perumahan

3. Hubungan sebab dan akibat pada sektor kesejahteraan sosial

4. Hubungan sebab dan akibat pada sektor publik

Bertolak dari sistem-sistem diatas, kesimpulan hubungan sebab dan akibat di atas maka dapat dirumuskan dalam bentuk diagram alir model penyelenggaraan social housing. Model ini memberikan masukan penilaian lebih dalam dan secara kritis sesuai dengan kondisi di Indonesia seperti ditunjukkan pada diagram 1 . Digram Alir Model Penyelenggaraan Social Housing berikut:

Analisa Kritis dilakukan pada digram Alir Model Penyelenggaraan Social Housing untuk mendapatkan penajaman kajian dari pemahaman lebih dalam tentang:

1. Keberadaan social housing dalam kapasitas sebagai welfare state ${ }^{14}$ meskipun Indonesia bukan merupakan negara yang menganut sistem ini.

2. Rentang pemahaman cara memenuhi kebutuhan perumahan (kota) dan implementasinya, khususnya bagi

penyelenggaraan social housing sesuai dengan kemampuannnya dalam mengambil keputusan politis dan menyelenggarakan pembangunan.

${ }^{14}$ Implikasi sebagai welfare state adalah kewajiban negara dalam memberikan kesejahteraan bagi masyarakat, sebagaimana disyaratkan dalam perundang-undangan. Peningkatan kesejahteraan dilakukan berupa kesejahteraan umum/publik, kelompok secara kolektif ataupun perorangan/individu. masyarakat berpenghasilan rendah pada praktek-praktek penyelenggaraan social housing ${ }^{15}$.
15 Praktek-praktek pengadaan perumahan yang mendekati konsep penyelengaraan social housing bertolak dari karakter yang telah dikaji sebelumnya. Karakter ini berupa kebijakan-kebijakan politis

untuk (i) memenuhi standar sosial dalam lingkup ekonomi (kesejahteraan) (ii) melakukan penyediaan produk layanan sosial tersebut (dalam bentuk perumahan) dan (iii) memenuhi kebutuhan masyarakat akan rumah untuk bertempat tinggal Indikasi penyelenggaraan yang dipandang sebagai social housing di Indonesia adalah dalam bentuk Rumah Susun Sewa Sederhana (rusunawa) dan Perumahan Swadaya, Pembangunan Rumah Susun Sewa Sederhana ini lebih mengarah kepada 'newdevelopment' sedangkan Perumahan Swadaya lebih mengarah kepada 'housing-improvement'. Kedua program ini lebih cenderung menjadi 'support assistance' pada konteks perkotaan dan urban renewal. Indikasi lain adalah pembangunan perumahan oleh instansi seperti rumah dinas, mess dan sebagainya. 


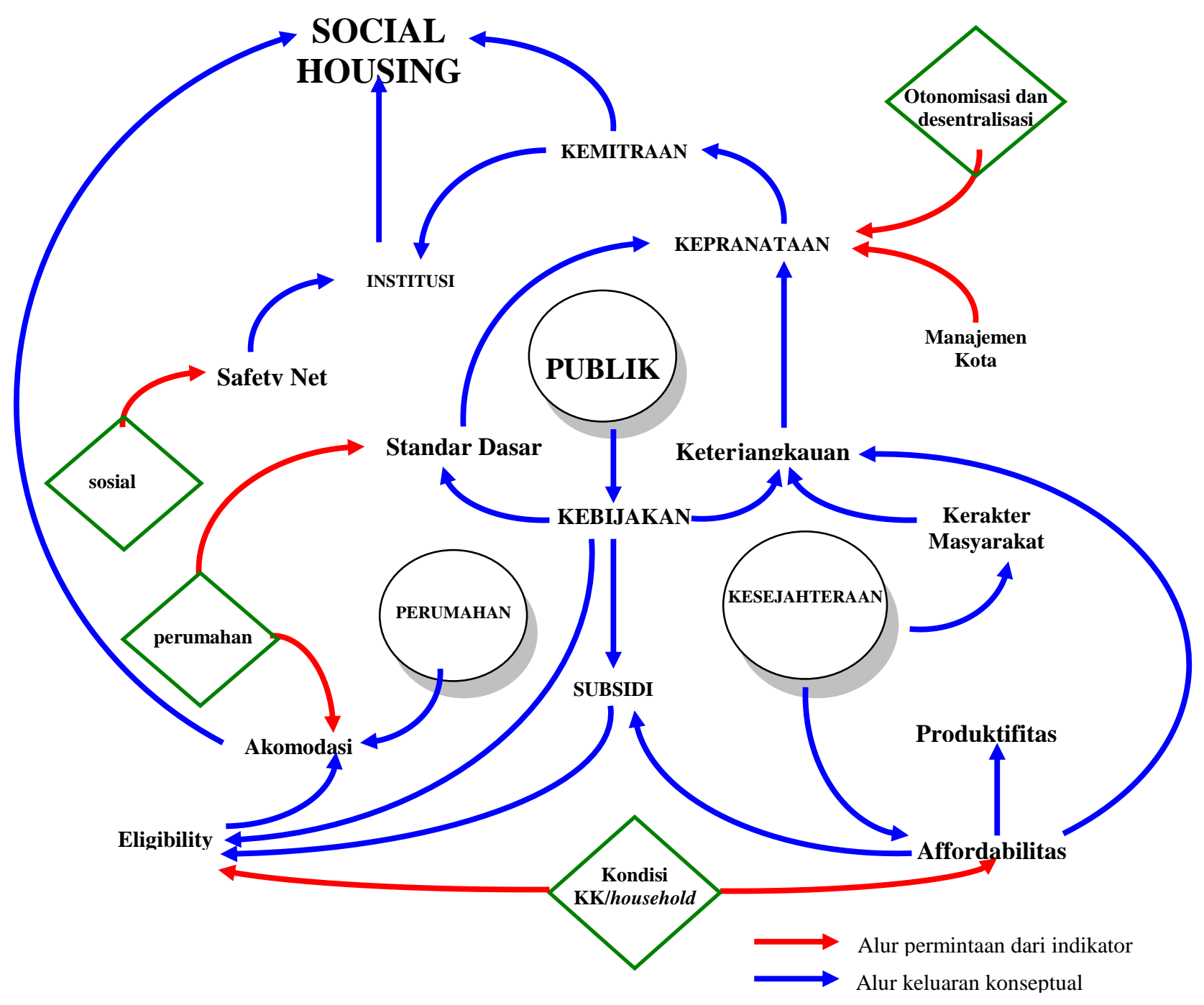

Gambar 1. Diagram Alir Model Penyelenggaraan Social Housing

Hal tersebut diatas menjelaskan bahwa pemahaman penyelenggraaan social housing memiliki rentang yang luas. Rentang ini meliputi mulai dari sifat pembangunan perumahan oleh sektor publik hingga dibangun sendiri secara swadaya oleh masyarakat ${ }^{16}$. Pada

\footnotetext{
${ }^{16}$ Keduanya berangkat dari adanya (urban) social movement. Pada public housing berawal dari social movement yang mampu menggerakan peran/tanggungjawab sektor publik (pemerintah)
}

satu sisi penyelenggaraan perumahan dilakukan oleh pemerintah. Pembangunan perumahan ini merupakan bagian dari penanganan masalahmasalah (sosial) perumahan di perkotaan yang disebut sebagai public housing. Sebaliknya

menyediakan (minimal dalam bentuk kebijakanpolitical responsibility) pemenuhan kebutuhan rumah sedangkan community based housing menempatkan social-community development dalam kerangka housing development. 
pembangunan perumahan dengan sifat swadaya atau dilakukan sendiri oleh masyarakat, baik melalui kelompok bersifat kolektif memberikan pemahaman yang berbeda. Pembangunan perumahan ini bertumpu pada kemampuan kelompok/komunitas atau community-based housin., sebagaimana pada Ilustrasi 3.1,

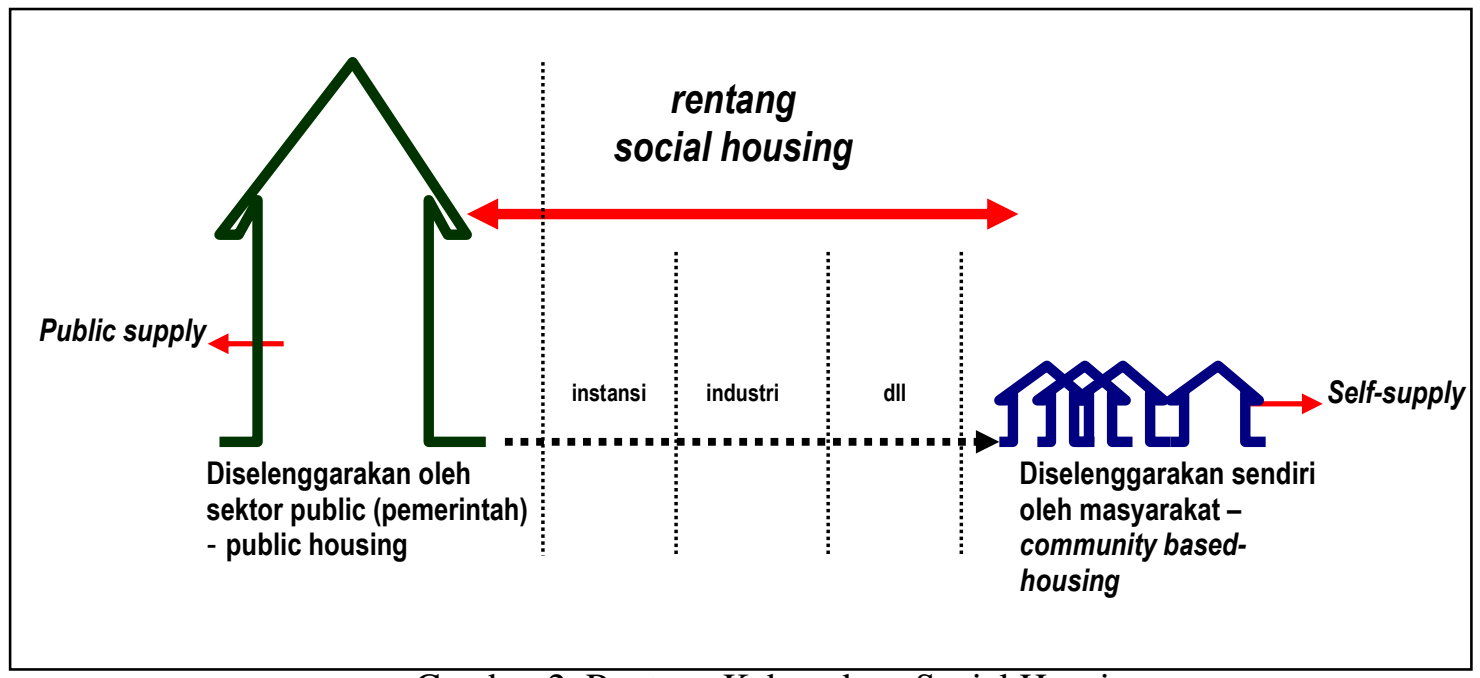

Gambar 2. Rentang Keberadaan Social Housing

\section{Pelaku dan sistem penyelenggaraan}

Melalui pendekatan institusi maka pemerintah memiliki kemampuan dan perangkat untuk melakukan sistem penyediaan perumahan melalui social housing. Perangkat ini merupakan sistem delivery dalam penyediaan perumahan dan mengembangkan pengelolaan/manajemen. Hal ini memiliki tujuan untuk mengakomodasi karakter masyarakat urban memenuhi kebutuhan perumahan untuk pengembangan produktifitas. Manajemen ini dapat dalam bentuk badan otorita penyedia social housing seperti di beberapa negara atau dikelola langsung oleh pemerintah daerah/lokal melalui dinas/instansi teknis (Dinas Perumahan). Badan otorita ini akan merumuskan kriteria eligibilitas bagi kelompok sasaran seperi melalui sertifikasi untuk menunjukkan kualifikasi kelompkm sasaran dan mekanisme akomodasi yang dapat dilakukan melalui waiting list, multiple choice, need demand.

\section{SIMPULAN}

Riset yang telah dilakukan menyimpulkan bahwa social housing memiliki prospek di Indonesia. Namun prospek ini memerlukan rasionalisasi sesuai dengan kondisi di Indonesia dengan membangun karakter penyelengaraan social housing, dan mengembangkan kriteria dan parameter dari keberadaan social housing. Keberadaan social housing harus mampu mengintegrasikan atau menjadi katalisator antara housing right dan social welfare.

Rumusan pengertian kembali social housing lebih merupakan instrumen pembangunan (kesejahteraan) sosial melalui penyediaan perumahan sesuai dengan standar baku. Penyediaan dilakukan melalui kemitraan sebagai pengembangan sistem (delivery).

Sistem yang dikembangkan untuk mengendalikan akses dan alokasi pasar perumahan, sehingga social housing diselenggarakan berdasarkan stratifikasi karakter kelompok sasaran di perkotaan/urban 
dalam mengembangkan produktivitas melalui akomodasi perumahan.

Pokok-pokok temuan khusus meliputi pemahaman prospek sebagai kondisi yang harus dibangun untuk dapat menyelenggarakan social housing. Kondisi ini melahirkan karakter dan konsep yang mendasar dalam mendesain penyelenggaraan social housing. Hal ini menjadi masukan perumusan prinsip penyelenggaraan hingga akhirnya didapatkan pengertian baru yang aplikatif penyelenggaraan social housing di Indonesia dengan:

1. Membangun prospek pada kondisi di Indonesia yaitu apa karakter mendasar dari social housing yang mampu mengintegrasikan dan menjadi katalisator antara meningkatkan kesejahteraan dan memenuhi hak mendapatkan rumah bagi masyarakat.

Dengan demikian, mendatang, Prospek penyelenggaraan social housing lebih dipandang sebagai 2 (dua) prospek. Pertama, prospek dipandang dari membangun karakter penyelengaraan social housing untuk kondisi Indonesia. Dan kedua, prospek untuk mengembangkan kriteria dan parameter berdasar keberadaan social housing di Indonesia.

2. Karakter mendasar dan konsepsi penyelenggaraan yaitu bagaimana sebenarnya social housing ini diselenggarakan, dan seperti apa jika diselenggarakan di Indonesia.

Karakter (i) memandang social housing sebagai instrumen pembangunan (kesejahteraan) sosial melalui penyediaan perumahan.

Karakter berikutnya (ii), peran social housing merupakan pengembangan sistem penyediaan perumahan. Pengembangan yang dilakukan memiliki konsep delivery dengan memperhatikan standar dasar pembangunan perumahan.

Selanjutnya karakter (iii), social housing merupakan instrumen penyeimbang dalam pengendalian akses dan alokasi bagi kelompok masyarakat untuk dapat masuk pada pasar perumahan. Implementasinya melalui konsep manajemen subsidi untuk merancang subsidi agar mampu memberikan 'dampak' atau daya ungkit..

Dalam karakter (iv), social housing mengakomodasi karakter kelompok sasaran di perkotaan/urban. Karakter tersebut menekankan konsep keberpihakan dengan mengidentifikasi kapasitas bawaan/carryingcapacity kelompok sasaran dan pengembangan produktifitas selama proses akses fdan alokasi masuk ke social housing.

Karakter terakhir (v) menekankan social housing dapat menjawab kebutuhan akomodasi pengembangan produktivitas kelompok sasaran melalui penyediaan perumahan. Konsep akomodasi (perumahan) mendesain mekanisme ataupun prinsipprinsip untuk mendapat akomodasi social housing.

\section{SARAN}

Pemahaman kembali social housing memberikan konsekuensi membangun kondisikondisi yang mendukung prospek penyelenggaraan, yaitu:

1. Secara mendasar menyadari bahwa permasalahan yang paling rumit adalah lahan. Berikutnya, sifat dualistik dari kota di Indonesia, yaitu kota formal dan informal. Kedua hal tersebut menjadi perhatian dalam 'shelter for all'. Hal lain adalah kondisi sosial ekonominya yang beragam, sehingga membutuhkan banyak alternatif penyelenggaraan.

2. Penyelenggaraan mutlak sebagai social housing terutama dikaitkan dengan social security masih jauh dari kondisi yang ideal. Hal ini akan lebih baik dalam posisi sebagai public housing, walau dengan sebutan sebagai social housing. Arah pengembangan social housing lebih dalam rangka meningkatkan produktivitas. Dengan demikian social housing lebih potensial sebagai labour housing atau labor social housing .

3. Kebijakan social housing akan dapat terlaksana jika good governance dapat berjalan. Kondisi kedua adalah menciptakan political will dan peraturan 
yang jelas. Kondisi terakhir adalah menciptakan commitment policy perumahan dianggap sebagai upaya percepatan pembangunan prasarana.

4. Akhirnya, parameter yang dikembangkan dalam menyusun arahan program sebagai implementasi kebijakan penyelenggaraan social housing meliputi: Peran dari definisi social housing, Kerangka kerja kebijakan dan perundangan, Kerangka kerja institusi/kepranataan, Akses pendanaan dan pembiayaan social housing, Alokasi dan akses subsidi, Kesejahteraan social, dan, Desain model social housing.

\section{DAFTAR PUSTAKA}

Anonim, 2003, Social housing in the UNECE Region; Committee on Human Settlements UNECE - Work Shop on Social Housing, Prague Mei 2003.

Anonim, Demand-side Policy: Consumers Subsidies. Chapter 15 Housing Policy,

Bell, J., 2006, Doing your Research Project, Open University Press, McGraw Hill, (2005) diterjemahan: penerbit PT Indeks Gramedia Group,

Berry, K., 2003, Social Housing. www.scottish.parliament.uk.

Black, J.A. dan Champion, D.J., 1999, Metoda dan masalah Penelitian Sosial, Penerbit PT Refika Aditama, Bandung.

Cahyat, A., 2004, Beberapa model penghitungan kemiskinan di Indonesia, Poverty \& Decentralization Project CIFOR (Center for International Forestry Research) - BMZ (Bundesministerium für Wirtschaftliche Zusammenarbeit und Entwicklung).

Davis, S., 1995, The Architecture of Affordable Housing, University of California Press Ltd, London UK.
Departement of the Environment and Local Government., 1999, Social Housing Guideline - Design Guideline. Goverment of Ireland.

DeTombe, Dorien, Handling Complex Societal Problems, Chapter 17 dalam http://www.geocities.com/doriendetom be/index.html

Dublin Dockland Development Authority, 2004, Social/Affordable Housing, Policy Document Journal. January 2004

Etten, J.V., 2004, Social Housing in the Netherlands, Lessons Learned for Indonesia?. Proseding Sistem Perumahan Sosial, Pusat Studi Metropolitan dan IAP.

Gibb, K., 2000, Modeling Housing Choice and Demand in a Social Housing System : The Case of Glasgow. Berkeley Program on Housing and Urban Policy; University of California Berkeley.

Hall, P., 1988, Cities Of Tomorrow, Blackwell Publishers Ltd, London.

Hernowo, B., 2004, Socio-Economic Implication and Values of Housing. Proseding Sistem Perumahan Sosial, Pusat Studi Metropolitan dan IAP.

Katsura, H.M. and Struyk, R.J., 2003, Selling Eastern Europe's Social Housing Stock: Proceed with Caution. The Urban Institute Journal - Housing Policy Debate, Volume 2- issue 4.

Kirmanto, D., 2004, Rumah Sosial di Indonesia: Tinjauan Kebijkan dan Program bantuan Perumahan Pemerintah, Proseding Sistem Perumahan, Penerbit Pusat Studi Metropolitan dan IAP. 
Kuswartojo, Tjuk, dkk., 2005, Perumahan dan Permukiman di Indonesia; Upaya Membuat Perkembangan Kehidupan yang Berkelanjutan, Penerbit ITB, Bandung.

Lowe, S., 1986, Urban Social Movement (The City After Castells), Macmillan Education Ltd, London.

Santoso, J., dan Hadar, Ivan A., 2004, Proseding Sistem Perumahan Sosial Belajar dari Pengalaman Jerman. Penerbit Pusat Studi Metropolitan dan IAP.

Social Housing and Private Finance, 2000, Current Trends and Future Prospect; Housing Finance Journal No.47. August 2000. 